\title{
Socio-ecological perspective of local bio-resources based production system of palm sugar and palm flour from aren (Arenga pinnata): Case study of Sukaresmi Village, West Bandung, Indonesia
}

\author{
SUSANTI WITHANINGSIH ${ }^{1,2,3,}$, PARIKESIT $^{1,2,3}$, JOHAN ISKANDAR $^{1,2,3,}$, RISYA PUTRI $^{1}$ \\ ${ }^{1}$ Department of Biology, Faculty of Mathematics and Natural Sciences, Universitas Padjadjaran. Jl. Raya Bandung-Sumedang Km. 21 Jatinangor \\ Sumedang 45363, West Java, Indonesia. Tel.: +62-22-7796412 ext. 104, Fax.: +62-22-7795545. ^email: susanti.withaningsih@unpad.ac.id \\ ${ }^{2}$ Center for Environment \& Sustainability Science, Universitas Padjadjaran. Jl. Sekeloa Selatan No. 1, Bandung 40132 Indonesia \\ ${ }^{3}$ Graduate School of Sustainability Science, Universitas Padjadjaran. J1. Dipatiukur No. 35, Bandung 40132, Indonesia
}

Manuscript received: 24 February 2019. Revision accepted: 28 June 2019

\begin{abstract}
Withaningsih S, Parikesit, Iskandar J, Putri R. 2019. Socio-ecological perspective of local bio-resources based production system of palm sugar and palm flour from aren (Arenga pinnata): Case study of Sukaresmi Village, West Bandung, Indonesia. Biodiversitas. 20: 1990-1997. The heterogeneity of landscapes, from a socio-ecology viewpoint, has resulted in the emergence of various systems of production for the same end products, which have developed with wide variations and distinctiveness and are based on the local availability of bio-resources. Even on landscapes with extreme biophysical and social conditions, various systems of production can still be encountered. Bio-resource-based systems generally exist on a small scale and in poorly-resourced communities. This study aimed to determine the use of local bio-resources and palm management techniques in different systems used for the production of palm sugar and palm flour. This study utilized a combination of qualitative and quantitative methods. Primary data were collected using structured and semi-structured interviews, observations, and participants' observations. The results showed that palm sugar was processed by peeling the midrib, passing, tapping, and making the midrib into sugar, whereas palm flour was processed by cutting down trees, grating, squeezing, and precipitating the end product. The local bio-resources used in the production of both included Chinese albizia (Albizia chinensis), giant bamboo (Dendrocalamus giganteus), tali bamboo (Gigantochloa apus), kemang (Mangifera kemanga), jackfruit (Artocarpus heterophyllus), and sobsi (Maesopsis eminii). Local knowledge regarding the processing of palm sugar was passed from generation to generation, whereas the knowledge regarding the processing of palm flour was achieved through independent learning and asking questions.
\end{abstract}

Keywords: Extreme landscape, local bio-resources, palm flour, palm sugar, production system

\section{INTRODUCTION}

The diverse socio-ecological conditions of rural landscapes in Indonesia has produced diverse production systems, many of which rely on local biological resources as their primary raw materials. In addition, rural production systems typically involve poorly-resourced communities and are performed on a small scale. One indication of poorly-resourced communities is the control of local biological resources as raw materials. These conditions result in uncertainty regarding the ability to sustain production systems. However, these small-scale local resource-based production systems play important roles in the economic activities on regional, national, and global scales.

Many local resource-based production systems can be found even in extreme landscape conditions. By definition, an extreme landscape is a landscape that has extreme biophysical characteristics, such as steep to very steep topographic conditions, and is prone to natural disasters (landslides, floods, droughts, and earthquakes). From a social context, extreme landscapes can be characterized by the social conditions of vulnerable local communities, such as high poverty rates, a lack of access to adequate natural resources for the majority of the population, and high potential for social conflicts. In the rural areas of West Java, many production systems rely on the local biodiversity and occur in extreme landscape conditions. For example, palm-based production systems (Arenga pinnata (Wurmb.) Merr) locally known as aren usually involve a poorly-resourced local community, in terms of the availability of capital, raw materials, and market access. The socio-economic importance of aren (Arenga pinnata) and other palm species for the rural poor is described by Dalibard (2007).

Aren is a natural resource often found in rural areas, with a widespread distribution that is easily available to local communities as a sustainable resource. Aren is the most important sugar palm of the humid tropics. Besides yielding sugar, it provides a great number of products and benefits to its users, and is one of the most diverse multipurpose tree species in culture. Aren fruits can be processed for making pickles, juices, desserts, for canned foods, and also being cooked for making traditional sugary syrup (Ishak et al. 2012). Thatch (black fiber) or locally known as ijuk is used for making ropes, brooms, brushes, paintbrush, septic tank base filter, roofing, fishing tools and for handicraft (Miller 1964; Sastra et al. 2006; Bachtiar et al. 2008; Leman et al. 2008). Aren trees have been around for making variety of by-products for hundreds of years 
(Tomlinson 1962; Ishak et al. 2012). In Indonesia, aren is multipurpose tree species widely used by different ethnic groups, particularly in North Sulawesi, South East Sulawesi, North Sumatra, West Java, Central Java, East Java, East Kalimantan and West Kalimantan (Mogea et al. 1991). There are four main aren product with economic value: alcoholic beverage, sugar, thatch (ijuk) and aren fruits (kolang kaling) (Martini et al. 2012).

Aren plays important ecological, economic and sociocultural roles in local communities. Ecologically, aren trees can protect the soil from erosion due to their strong roots. In terms of socio-economy and culture, aren trees are used for various traditional purposes; for example, palm sugar flowers are tapped for use in a typical Sundanese drink called tuak, and they can also be made into palm sugar (Gunawan et al. 2018).

Aren is a versatile plant because all parts of the tree can be used: the roots are used in traditional medicines, the trunk is used in various types of equipment and buildings, and young leaves are used as cigarette paper wrappers. Young palm fruit can be processed into kolang-kaling, the tapped sap (called nira) can be used to make brown sugar and vinegar, and the starch or flour found in the trunk can be used as an ingredient in various foods (Irawan et al. 2009). The use of nira in the production of fresh drinks or as the raw materials for sugar has provided many benefits to communities in and around the forest.

The local community in Sukaresmi, West Bandung District has long known how to use and process aren using traditional methods. The local knowledge of this community can be applied during their daily lives, ranging from tapping aren trees, making palm sugar and palm flour, making kolang-kaling, and making ijuk fibers, and the activities associated with tapping and processing palm sugar represent sources of livelihoods in Sukaresmi, West Bandung District.

The population of aren trees in Sukaresmi, West Bandung District is currently declining due to land being cleared to build dams and being converted to agricultural land. In addition, a number of palm trees are old and unproductive, causing the increasing scarcity of trees available for palm sugar production, due to the absence of efforts to cultivate palm sugar trees (Mujahidin et al. 2003). Most members of the local community do not know how to properly cultivate palm sugar trees, and the process of cultivating trees in local communities is often dependent on the common palm civet (Paradoxurus hermaphroditus). Common palm civets spread and sow palm seeds by eating the palm sugar fruit and eliminating palm seeds with their excrement. Palm sugar seeds mixed with civet droppings can develop into seedlings in various habitats, such as fields, secondary forests, gardens, and taluns (annual perennial rotation gardens) (Siregar 2016). However, common palm civets are becoming scarce due to illegal poaching.

The skills to utilize and to process aren in Sukaresmi is currently declining because the skills to do these activities are passed from generation to generation on a domestic scale. Thus, without a proper regeneration to the younger population, this local knowledge is in danger of eradication. The process of turning aren trees into palm sugar and palm flour utilizes the biological resources available around Desa Sukaresmi. This study was conducted to determine the local biological resources that are used in the production systems that convert palm trees into palm sugar and palm flour in Sukaresmi, Rongga Subdistrict, West Bandung District.

\section{MATERIALS AND METHODS}

The study was conducted in 2018 at Sukaresmi, Rongga Sub-district, West Bandung District, West Java Province, Indonesia (Figure 1). Data from the statistical surveys done in this village show that the population in Desa Sukaresmi in 2018 was 8.477 from 2.587 households. The main occupations of the people were farmers, labors both for farms and other off-farm occupations, and traders. Ninetyone out of 2.587 households were farmers who were intensively involved in managing and utilizing the sugar palm trees for palm sugar (66) and palm flour (25).

This study used a mixed method that combined qualitative and quantitative data. Data collection techniques included the following: observations; semi-structured interviews, using interview guidelines for key informants; structured interviews, using questionnaires administered to randomly selected respondents; and participatory observations. Participant observation was carried out by involving the researchers doing some activities, such as going to garden, tapping the sap and processing the sap to make sugar and also asking some question to informants in relation to activities being done. The primary data and reports analyzed by cross-checking, summarizing and synthesizing, and making narrative account with descriptive analysis and evaluative (cf. Newing et al. 2011).

\section{RESULTS AND DISCUSSION}

The process of tapping palm sugar and producing palm flour was performed entirely by men because the processes involved in the utilization of palm sugar require expertise, including the skill to climb trees and the use of sigai to cut and transport the palm sugar, and the courage to remain on tall palm trees for extended periods of time. Women were usually involved in the production of palm sugar.

In general, the people in Sukaresmi produced palm sugar and palm flour during 2-7-year periods in regular intervals, but the production was not continuous due to its dependency on the presence of productive aren trees. not production was not continuous because the production of palm sugar and palm flour is very dependent on the presence of aren trees. Aren trees could be tapped for 1-5 months and required 5-12 months before they could be tapped again, while trees that were no longer tapped were used for the production of palm flour. In addition, business owner required sufficient capital to buy several aren trees that could be used for the production of palm flour. 


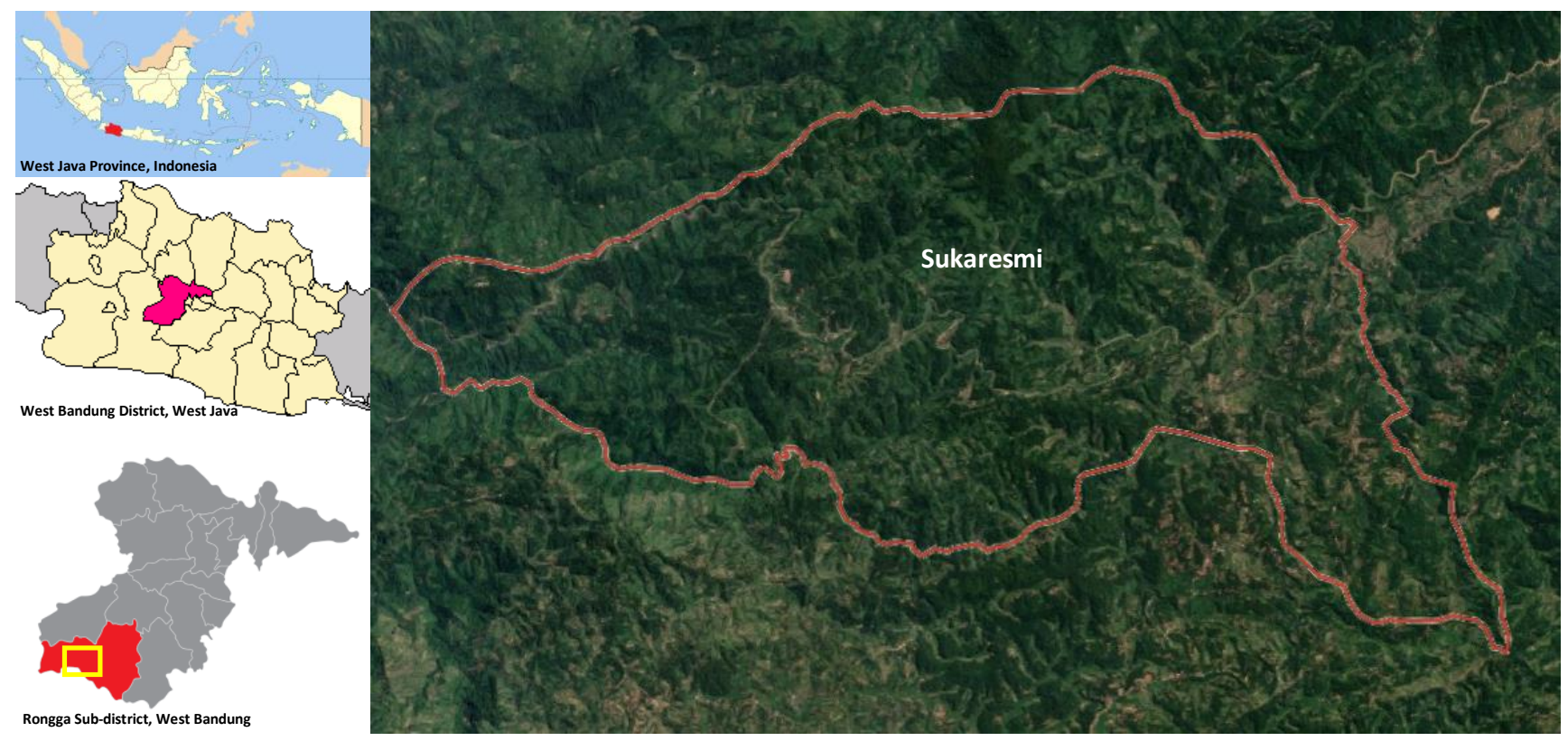

Figure 1. Map of Sukaresmi Village, Rongga Sub-district, West Bandung District, West Java Province, Indonesia

Based on the results of 66 respondents' interviews, the people in Sukaresmi acquired local knowledge regarding the conversion of palm sugar trees into palm sugar from older generations $(84.9 \%)$ and through autonomous learning $(15.1 \%)$. This result demonstrates that the knowledge regarding the process of making palm sugar was passed through generations. Starting in childhood, palm sugar tappers and producers learned the process of making palm sugar from their parents, from the tapping stage through the sugar making stage, who providing them with the knowledge of how to make palm sugar correctly. However, not all palm tappers were able to continue their involvement in the palm sugar trade because of the decline in palm sugar trees. Additionally, many of these people also tried other trades, such as becoming labors and traders, although continued efforts to make palm sugar could help preserve the existence of aren trees in Sukaresmi.

Different from the conversion of palm sugar trees into palm sugar, the knowledge of the community regarding the use of palm flour was mostly obtained through autonomous learning and asking other people (72\%), while only $28 \%$ obtained knowledge from the older generations. This result is in line with the fact that there were many areas overgrown with palm sugar trees in this region (2020 hectares) such as home yard, talun, and forest, which indirectly compelled the people to learn the production of palm sugar and palm flour autonomously

In the past, the people in Desa Sukaresmi did not know how to make palm flour; therefore, those wanting to learn this process had to learn from people outside of their village. Most palm flour traders obtained their knowledge of how to make palm flour from Sukabumi. The Sukaresmi community knew that the production of palm flour required a large amount of capital to buy the equipment and to build a processing plant; therefore, many people preferred to become tappers because tapping did not require as much capital. In addition, the process of making palm flour can reduce the presence of palm sugar trees in Desa Sukaresmi because many palm sugar trees have been cut down to be used as flour.

\section{Palm sugar production systems}

Based on the interview results, the tappers and palm sugar makers in Sukaresmi were aged between 17-45 years (38\%), 45-60 years (39\%) and over 60 years (23\%). This finding shows that most tappers and palm sugar makers in Sukaresmi were in their productive ages according to Febriyanti (2017). The workforce represents the population of people that are of productive age, between 15 to 64 years. Farming and labor were the main job of the palm sugar tappers, while tapping palm sugar trees represented their side jobs. The average palm tappers in Sukaresmi first began their tapping activities between the ages of 40-50 years, and after the age of 50, many tappers stopped because they were no longer strong enough to climb palm sugar trees, use sigai, and carry lodong.

The interviews result indicate that the process of tapping palm sap (nira) was still performed using traditional and simple tools produced by the community. In addition, raw materials for making these tools were derived from biological resources found in the forests and settlements around the Sukaresmi area. The tools used by the community to tap palm sugar are shown in Table 1.

The production of palm sugar in Sukaresmi was still performed traditionally, using self-made tools composed of raw materials found in Sukaresmi. The local communitysourced most of the raw materials used in these tools from the forest because these resources remained abundant, as shown in Table 2. 
Table 1. Tools for taping nira

\begin{tabular}{|c|c|c|c|c|c|}
\hline Activities & Tools & Materials & Usage & $\begin{array}{c}\text { How to } \\
\text { obtain }\end{array}$ & $\begin{array}{c}\text { Material } \\
\text { acquisition }\end{array}$ \\
\hline $\begin{array}{l}\text { Putting on } \\
\text { a sigai }\end{array}$ & Sigai & $\begin{array}{l}\text { Giant bamboo (Dendrocalamus } \\
\text { giganteus) for tall trees and } \\
\text { Tali bamboo (Gigantochloa } \\
\text { apus) for short trees }\end{array}$ & $\begin{array}{l}\text { Ladders to climb palm } \\
\text { sugar trees }\end{array}$ & Self-made & $\begin{array}{l}\text { Talun (annual } \\
\text { perennial } \\
\text { rotation } \\
\text { garden) }\end{array}$ \\
\hline $\begin{array}{l}\text { Peeling } \\
\text { midribs }\end{array}$ & $\begin{array}{l}\text { Bedog } \\
\text { (cleaver) }\end{array}$ & Iron & To peel the palm sugar midribs & Purchase & Blacksmith \\
\hline $\begin{array}{l}\text { Meninggur } \\
\text { and } \\
\text { mengayun }\end{array}$ & Paninggur & $\begin{array}{l}\text { Chinese albizia (Albizia } \\
\text { chinensis) and coffee (Coffea sp) }\end{array}$ & $\begin{array}{l}\text { To beat leungeun kawung to } \\
\text { enlarge the pores and facilitate } \\
\text { the Purchase release of the sap }\end{array}$ & Self-made & Forest \\
\hline Nira & Belt & Rubber and fabric & To hook cacangklek on the hip & Purchase & Fabric shop \\
\hline \multirow[t]{5}{*}{ tapping } & Cacangklek & Kemang wood (Mangifera kemanga) & To store the taping knife & Self-made & Forest \\
\hline & Kakait & $\begin{array}{l}\text { Iron and wood coffee (Coffea } \\
\text { sp)/guava wood (Psidium guajava) }\end{array}$ & To save and hook the lodong & Self-made & $\begin{array}{l}\text { Gardens and } \\
\text { blacksmiths }\end{array}$ \\
\hline & Safety rope & Rope and rattan (Calamus sp) & For tapper safety belts & Self-made & Forest \\
\hline & Lodong & $\begin{array}{l}\text { Giant bamboo (Dendrocalamus } \\
\text { giganteus) }\end{array}$ & To store the sap & Self-made & Talun \\
\hline & Tapping knife & $\begin{array}{l}\text { Iron and Chinese albizia (Albizia } \\
\text { chinensis) }\end{array}$ & $\begin{array}{l}\text { To cut the tip of the langri in } \\
\text { the leungeun kawung }\end{array}$ & Purchase & Blacksmith \\
\hline \multirow[t]{3}{*}{$\begin{array}{l}\text { Nira } \\
\text { tapping }\end{array}$} & Rope & $\begin{array}{l}\text { Ijuk rope (Arenga pinnata) / rattan } \\
(\text { Calamus } \mathrm{sp})\end{array}$ & $\begin{array}{l}\text { To tie lodong to the leaf } \\
\text { midribs }\end{array}$ & Self-made & Forest \\
\hline & Jeuntas & $\begin{array}{l}\text { Tali bamboo (Gigantochloa } \\
\text { apus)/Awi temen (Gigantochloa } \\
\text { verticillata) }\end{array}$ & $\begin{array}{l}\text { For tapper footings when } \\
\text { storing, tapping, and taking } \\
\text { lodong }\end{array}$ & Self-made & Talun \\
\hline & Lodong cover & Fabric & $\begin{array}{l}\text { To cover lodong when stored in } \\
\text { the palm sugar trees }\end{array}$ & Self-made & Fabric shop \\
\hline
\end{tabular}

Table 2. Tools for making palm sugar

\begin{tabular}{|c|c|c|c|c|c|}
\hline Activities & Tools & Materials & Usage & $\begin{array}{c}\text { How to } \\
\text { obtain }\end{array}$ & $\begin{array}{c}\text { Material } \\
\text { acquisition }\end{array}$ \\
\hline \multirow{5}{*}{$\begin{array}{l}\text { Heating Lahang } \\
\text { into sugar }\end{array}$} & Furnace & Soil & To cook sugar & Self-made & Garden \\
\hline & Wok & Iron & To heat lahang into sugar & Purchase & Blacksmith \\
\hline & Torch & Wood (Albizia chinensis) & To heat and make sugar & $\begin{array}{l}\text { Purchase } \\
\text { and forage }\end{array}$ & Forest \\
\hline & Sieve & $\begin{array}{l}\text { Woven bamboo and Ijuk (Arenga } \\
\text { pinnata)/plastic }\end{array}$ & $\begin{array}{l}\text { To sieve lahang from } \\
\text { lodong to the wok }\end{array}$ & Purchase & $\begin{array}{l}\text { Woven stores } \\
\text { and markets }\end{array}$ \\
\hline & $\begin{array}{l}\text { Suspension } \\
\text { board }\end{array}$ & $\begin{array}{l}\text { Tali bamboo (Gigantochloa } \\
\text { Apus) and iron }\end{array}$ & $\begin{array}{l}\text { To hold the sieve when } \\
\text { lahang is poured from } \\
\text { the lodong into the wok }\end{array}$ & Self-made & Talun \\
\hline Stirring sugar & Bagen & Teak Wood (Tectona grandis) & To stir sugar & Self-made & Forest \\
\hline \multirow[t]{2}{*}{ Taking peuеut } & Cemen & $\begin{array}{l}\text { Giant bamboo (Dendrocalamus) } \\
\text { giganteus) }\end{array}$ & $\begin{array}{l}\text { To contain peueut from the } \\
\text { wok }\end{array}$ & Self-made & Talun \\
\hline & Panyusur & Iron & $\begin{array}{l}\text { To clean the wok from the } \\
\text { leftover of the peueut }\end{array}$ & Purchase & Blacksmith \\
\hline Taking peuеut & Cocolek & $\begin{array}{l}\text { Tali bamboo (Gigantochloa } \\
\text { Apus) }\end{array}$ & $\begin{array}{l}\text { To take peueut from } \\
\text { cemen into ganduan }\end{array}$ & Self-made & Talun \\
\hline \multirow[t]{2}{*}{ Moulding sugar } & Ganduan & $\begin{array}{l}\text { Giant bamboo (Dendrocalamus) } \\
\text { giganteus)/chinese albizia (Albizia } \\
\text { chinensis) }\end{array}$ & $\begin{array}{l}\text { To mold sugar into sizes of } \\
10 \times 10 \mathrm{~cm} \text { (round shaped) } \\
\text { or } 5 \times 5 \mathrm{~cm} \text { (rectangle } \\
\text { shaped) }\end{array}$ & Self-made & $\begin{array}{l}\text { Forest and } \\
\text { Talun }\end{array}$ \\
\hline & Tatakan & $\begin{array}{l}\text { Wood of white siris (Albizia procera) } \\
\text { Wood of Indonesian bayleaf } \\
\text { (Syzigium polyanthum) }\end{array}$ & To store sugar molds & Self-made & Forest \\
\hline Wrapping sugar & Sugar wrap & $\begin{array}{l}\text { Young palm sugar leaves (Arenga } \\
\text { pinnata) }\end{array}$ & To wrap palm sugar & Self-made & Forest \\
\hline \multirow[t]{2}{*}{ Molding sugar } & Pamepes & $\begin{array}{l}\text { Castor bean (Ricinus communis) } \\
\text { Candlenut (Aleurites moluccana) } \\
\text { Coconut oil }\end{array}$ & $\begin{array}{l}\text { To harden sugar when } \\
\text { molded }\end{array}$ & Self-made & Forest \\
\hline & Raru & $\begin{array}{l}\text { Kawao root (Millettia sericea) and } \\
\text { mangosteen peel (Garcinia mangostana) }\end{array}$ & $\begin{array}{l}\text { To prevent sap from } \\
\text { becoming acidic when } \\
\text { putting in lodong }\end{array}$ & Self-made & Forest \\
\hline Storing sugar & Nyiru & Woven bamboo & To store sugar & Purchase & Store \\
\hline
\end{tabular}


Table 3. Biological resources utilized during palm sugar production

\begin{tabular}{|c|c|c|c|c|}
\hline \multirow{2}{*}{ Activities } & \multirow{2}{*}{ Tool name } & \multicolumn{2}{|c|}{ Biological resources } & \multirow{2}{*}{$\begin{array}{c}\text { Material } \\
\text { acquisition }\end{array}$} \\
\hline & & Local name material & Scientific name & \\
\hline \multirow[t]{2}{*}{ Putting on a Sigai } & Sigai & Awi gombong/ giant bamboo & Dendrocalamus giganteus & Talun \\
\hline & & Awi tali /tali bamboo & Gigantochloa apus & Talun \\
\hline Meninggur & Paninggur & Jengjeng/Chinese albizia tree trunk & Albizia chinensis & Forest \\
\hline \multirow[t]{3}{*}{ Tapping } & Cacangklek & Kemang & Mangifera kemanga & Forest \\
\hline & Kakait & Coffee tree stems & Coffea $s p$ & Garden \\
\hline & & Guava tree stems & Psidium guajava & Garden \\
\hline \multirow[t]{5}{*}{ Tapping } & Lodong & Awi gombong/giant bamboo & Dendrocalamus giganteus & Talun \\
\hline & Tapping knife & Jengjeng/chinese albizia tree trunk & Albizia chinensis & Forest \\
\hline & Rope & Kawung & Arenga pinnata & Forest \\
\hline & & Hoe & Calamus sp & Forest \\
\hline & Jeuntas & Awi Tali /tali bamboo & Gigantochloa apus & Talun \\
\hline Tapping & Jeuntas & Awi Temen/andong bamboo & Gigantochloa verticillata & Talun \\
\hline Heating Lahang into & Torch & Jengjeng/chinese albizia tree trunk & Albizia chinensis & Forest \\
\hline \multirow{2}{*}{ sugar } & & Kawung & Arenga pinnata & Forest \\
\hline & & Durian tree trunk & Durio zibertinus & Garden \\
\hline \multirow[t]{2}{*}{ Sieving Lodong } & Sieve & Awi Tali/tali bamboo & Gigantochloa apus & Forest \\
\hline & Suspension Board & Awi Tali/tali bamboo & Gigantochloa apus & Forest \\
\hline \multirow[t]{3}{*}{ Stirring Peиеиt } & Bagen & Teak wood & Tectona grandis & Talun \\
\hline & Cemen & Awi gombong/giant bamboo & Dendrocalamus giganteus & \\
\hline & Cocolek & Awi Tali/tali bamboo & Gigantochloa apus & \\
\hline Molding sugar & Ganduan & Awi gombong/ giant bamboo & Dendrocalamus giganteus & Talun \\
\hline \multirow[t]{3}{*}{ Moulding sugar } & Ganduan & Jengjeng/Chinese albizia tree trunk & Albizia chinensis & Forest \\
\hline & Tatakan & Kihiang tree & Albizia procera & Forest \\
\hline & & Salam/ Indonesian bay leaf & Syzygium polyanthum & Garden \\
\hline Wrapping sugar & Sugar Wrap & Kawung ngora & Arenga pinnata & Forest \\
\hline \multirow[t]{2}{*}{ Mepes } & Pamepes & Kenikir/castor bean & Ricinus communis & Forest \\
\hline & & Kemiri/candlenut & Aleurites moluccana & Garden \\
\hline \multirow[t]{2}{*}{ Raru } & Raru & Kawao root & Milletia sericea & Forest \\
\hline & & Mangosteen skin & Garcinia mangostana & Forest \\
\hline
\end{tabular}

The production of palm sugar in Sukaresmi, West Bandung Regency continues to utilize natural resources from the area, such as forests, gardens, and yards. The community used biological resources to make the tools used to tap and produce palm sugar. The community uses these biological resources because they remain abundant in nature and therefore do not require a large amount of capital. The utilization of biological resources during the production of palm sugar is presented in Table 3 .

As shown in Table 3, the most widely used biological resources to make palm sugar production tools were Chinese albizia (Albizia chinensis), giant bamboo (Dendrocalamus giganteus), tali bamboo (Gigantochloa apus), and palm sugar (Arenga pinnata). In addition, most of the raw materials were obtained from the forests in Desa Sukaresmi. Chinese albizia (Albizia chinensis), or sengon, is a plant in the Fabaceae family that is $30-43 \mathrm{~m}$ high and $70-140 \mathrm{~cm}$ in diameter, with round stems, bipinnate leaves with acute tips, and obtuse-based with an opposite leaf position (Orwa et al. 2009).

Chinese albizia is widely used in the production of palm sugar because it is easy to find and abundant in Sukaresmi, especially in Dusun Cimarel. Based on interviews with the informants, wood from Chinese albizia trees is white to brownish in color, coarsely textured, light, durable, and termite resistant, making it a common option for building in the local community. This description is in accordance with the description by Orwa et al. (2009) that sengon or
Albizia chinensis is light, soft, durable, resistant to termites and insects, and is widely used to build houses.

Giant bamboo (Dendrocalamus giganteus) is the largest known variety of bamboo. This bamboo is also classified as the tallest bamboo in the world, which in tropical condition can reach its potential height of 30 meters. The clusters do not grow too tightly, and its upright reeds reach $30 \mathrm{~cm}$, with a diameter of $18-25 \mathrm{~cm}$, sections that are $25-50 \mathrm{~cm}$ in length, a thickness of up to $2.5 \mathrm{~cm}$, and dark brown midribs (Schoder 2010). Bamboo gombong was used by the community during sugar production because of its large size, endurance, and abundance, and it has often been used for construction and housing. Sembilang or giant bamboo stems are often used for the construction of buildings and housing, water pipes, paper production, and for home components, such as boards, walls, and floors, because they have thick and durable walls (Zulkarnaen 2015).

Tali bamboo (Gigantochloa apus) is a bamboo species with tight sympodia, tight clusters, and upright positions. Rural communities, especially on the islands of Java and Bali, have planted tali bamboo to utilize their trunks for various purposes, including building construction materials (houses and bridges), household appliances, furniture crafts, house roofs, and traditional musical instruments (angklung) (Sujarwo et al. 2010). Tali bamboo is used in a variety of tools used in palm sugar production because it is durable, small in size, and easy to use. 
Table 4. Equipment for processing palm flour

\begin{tabular}{|c|c|c|c|c|c|}
\hline & Equipment & Material & Usage & $\begin{array}{l}\text { How to } \\
\text { obtain }\end{array}$ & $\begin{array}{l}\text { Material } \\
\text { acquisition }\end{array}$ \\
\hline $\begin{array}{l}\text { Checking palm } \\
\text { flour }\end{array}$ & Panyongcong & $\begin{array}{l}\text { Iron and Chinese albizia } \\
\text { (Albasia/Albizia chinensis) }\end{array}$ & $\begin{array}{l}\text { Tool to check for palm flour } \\
\text { in palm sugar trunk }\end{array}$ & Self-made & $\begin{array}{l}\text { Forest and } \\
\text { blacksmith }\end{array}$ \\
\hline \multirow[t]{2}{*}{$\begin{array}{l}\text { Cutting palm sugar } \\
\text { trunk }\end{array}$} & Saw & Iron & $\begin{array}{l}\text { To cut down the palm } \\
\text { sugar trunk }\end{array}$ & Purchase & Blacksmith \\
\hline & $\begin{array}{l}\text { Axe or } \\
\text { machete }\end{array}$ & Iron & To cut palm sugar & Purchase & Blacksmith \\
\hline \multirow[t]{2}{*}{$\begin{array}{l}\text { Grating palm } \\
\text { sugar trunks }\end{array}$} & $\begin{array}{l}\text { Grating } \\
\text { machine }\end{array}$ & $\begin{array}{l}\text { Iron and jackfruit wood } \\
\text { (Artocarpus heterophyllus) }\end{array}$ & $\begin{array}{l}\text { To grate the palm sugar } \\
\text { trunk into coarse fibres }\end{array}$ & Purchase & $\begin{array}{l}\text { Electronic } \\
\text { appliance shop }\end{array}$ \\
\hline & Shovel & Iron & $\begin{array}{l}\text { To shovel the flour fibres, } \\
\text { which will be put in a } \\
\text { squeezer }\end{array}$ & Purchase & Blacksmith \\
\hline $\begin{array}{l}\text { Squeezing } A c i \\
\text { fibres }\end{array}$ & Squeezer tub & Wall & To squeeze flour fibres & Self-made & Hardware stores \\
\hline $\begin{array}{l}\text { Squeezing } A c i \\
\text { fibres }\end{array}$ & Strap & Ropes & $\begin{array}{l}\text { To hold the hands } \\
\text { when palm flour was } \\
\text { squeezed }\end{array}$ & Self-made & Store \\
\hline Sieving aci fibres & Sieve & Filter cloth & $\begin{array}{l}\text { To sieve impurities from } \\
\text { flour fibres }\end{array}$ & Purchase & Fabric shop \\
\hline \multirow[t]{2}{*}{ Precipitating $A c i$} & Container tub & $\begin{array}{l}\text { Wall or sobsi wood/African } \\
\text { wood (Maesopsis eminii) }\end{array}$ & To precipitate flour & Self-made & $\begin{array}{l}\text { Forest and } \\
\text { building shop }\end{array}$ \\
\hline & Broom & Plastic rope & $\begin{array}{l}\text { To clean the palm flour so } \\
\text { that it looked clean and } \\
\text { white }\end{array}$ & Self-made & Store \\
\hline
\end{tabular}

Table 5. Biological resources used during palm flour production

\begin{tabular}{lllll}
\hline Activities & $\begin{array}{l}\text { Name of } \\
\text { equipment }\end{array}$ & Biological resources & & $\begin{array}{l}\text { Origin of } \\
\text { manufacture }\end{array}$ \\
\cline { 2 - 4 } & Local name & Latin name & Forest \\
Checking $a c i$ & Panyongcong & Jengjeng/Chinese albizia & Albizia chinensis & Garden \\
Grating palm sugar trunks & Grating machine & Jackfruit & Artocarpus heterophyllus & Forest \\
Precipitating $a c i$ & Container tub & Sobsi/Africa & Maesopsis eminii & Forest \\
Precipitating $a c i$ & Broom & Awi tali/tali bamboo & Gigantochloa apus & Forest \\
Drying $a c i$ & Suspension Board & Awi gombong/ giant & Dendrocalamus giganteus \\
& & bamboo & & \\
\hline
\end{tabular}

Palm sugar is marketed by palm sugar makers to neighbors, dealers or collectors around the community and to retailers from outside of the village who will buy the sugar for resale. Marketing bodies involved in the marketing process of palm sugar are middlemen, wholesalers, sales agents, and retailers (Purba 2014).

\section{Palm flour production system}

According to the interviews with respondents, the palm flour makers in Desa Sukaresmi included those who were between $15-30$ years old $(36 \%), 30-45$ years $(40 \%)$, and 45-60 years old $(24 \%)$; therefore, the makers of palm flour were primarily in their productive ages.

Before processing, several considerations must be taken, such as the preparation of tools, the preparedness of the trees, and the knowledge of the flour production process, which can all affect the quality of the produced palm flour. The tools used by the people of Sukaresmi were either selfmade from raw materials sourced from the forests around the village or purchased from blacksmiths and hardware stores (Table 4).

Table 5 shows that the biological resources used during palm flour production, include Chinese albizia, jackfruit, sobsi, tali bamboo, and giant bamboo. The raw materials for these tools were primarily sourced from the forest because they are abundant in the forest and widely used by the local communities.

Jackfruit plants (Artocarpus heterophyllus Lamk) are extremely versatile plants because all parts of these plants, especially their wood, can be used for various purposes. Jackfruit wood is used during palm flour production because it is strong and durable, making it widely used by the community. According to Komarayati (1993) jackfruit wood has the potential to be used as building construction materials because jackfruit wood is quite durable, strong, resistant to termites or mold, and has an interesting pattern.

Sobsi wood is used for the precipitation of flour because of its rough texture and durability. Sobsi wood or 
African wood (Maesopsis eminii Engl.) is a type of forest plant belonging to Rhamnaceae family. This African wood is in exotic and fast-growing species, and is used as a building material for light construction, containers, boxes, and plywood. Part of the African wood is almost white in color, while the sapwood is yellowish when wet and turns golden brown or dark brown after being exposed to air for a long time. The texture of the wood is rough, with crossed fibres, producing a pattern on the surface of the board (Orwa et al. 2009).

The people in Sukaresmi used unused palm flour fibres as animal feed. The palm flour waste can also be used to produce mushrooms, including jamur kancing/ button mushroom (Agaricus bisporus). The people of Desa Sukaresmi were fond of button mushrooms for their good taste, and they searched for these mushrooms within the palm flour waste along riverbanks. A. bisporus or button mushrooms are one of the oldest types of mushroom in the world and are very popular in the diet of this region. Wild A. bisporus were referred for customer due to their flavor and texture (Sadiq et al. 2008)). This mushroom has a luscious taste with more nutritional value has very good aroma or flavoring taste is used as food and in food industries (Misharina et al. 2010). It is considered to have high biological activity, low toxicity and has significance folklore and ethnopharmacological significance. This type of mushroom also contains high levels of linoleic acid and aromatase enzymes, which catalyze sex hormones in humans. A. bisporus has many functions, such as antioxidant, anti-bacterial, anti-inflammatory, anti-tumor, and body immune system function, making it beneficial for daily consumption (Falguera et al. 2011).

\section{Aren (Arenga pinnata) tree management}

Based on the result of the interviews, mostly planters of palm sugar trees in Sukaresmi $(68 \%)$ did not have their own palm sugar tree plantations. They buy the palm sugar trees and tapping them on land owned by local residents or Perhutani (Indonesia State Owned Forestry) to make palm sugar or palm flour. On the other hand, people who owned their own plantations (32\%), which was usually inheritance, would use the palm sugar trees on their land.

In general, the people in Sukaresmi did not cultivate the palm sugar trees, because the palm sugar trees are naturally dispersed by common palm civets (Paradoxurus hermaphroditus). In many areas, farmers believe that the best aren planters are the palm civet (Mogea et al. 1991). Palm sugar planters in Sukaresmi paid less attention to the management and development of palm sugar due to their lack of knowledge regarding the practice. Planters obtained knowledge regarding the management of palm sugar trees through autonomous learning. Palm sugar trees that grew naturally were allowed to grow where they were. The management and cultivation of palm sugar trees performed by palm sugar trees planters in Sukaresmi were limited to weeding around palm trees, by hacking the weeds; however, the trees were not given any fertilizer nor were they controlled for pests and diseases.

Furthermore, the palm sugar management systems in Sukaresmi were divided into two types: the management of palm sugar trees by Perhutani and the management of palm sugar trees by the local communities. These management systems remained limited to the seedling level and did not reach the level of tree management because it still required the aid of common palm civets. The management of palm sugar by Perhutani was performed by burning the land to be used for nurseries. The goal was to make the soil more fertile and to eliminate the grass and plants around the palm sugar trees. The palm sugar seeds used by Perhutani were obtained from the central research and development center in Wonosobo. The location for the management of palm sugar seeds provided by Perhutani is in Dusun II Cikarang. In contrast, the management performed by local communities was called dicaangan and involved removing grass from around the seedlings of palm sugar trees using sickles.

In conclusion, the findings of this study show that the availability of local biological resources is an important factor for the processing of aren (Arenga pinnata) both for the production of palm sugar and palm flour. Some important resources involved in both production systems are Chinese albizia (Albizia chinensis), tali bamboo (Gigantochloa apus) and giant bamboo (Dendrocalamus giganteus) which were used for tapping nira, producing palm sugar and palm flour. These biological resources are especially important for the production of palm sugar which used 14 bioresources compared to the production of palm flour which used five bioresources because the latter mostly requires machines and tools made of iron.

Additionally, the knowledge regarding aren tree management within the local community was obtained through autonomous learning but this was not maximized because the communities continued to rely on common palm civets to spread the palm sugar seeds.

\section{ACKNOWLEDGEMENTS}

This study was supported by the Indonesian Ministry of Research Technology and Higher Education, through Penelitian Dasar. The authors would like to thanks Fahru Rozi with the field team and Annas Dwitri Malik for his assistance during manuscript preparation.

\section{REFERENCES}

Bachtiar D, Sapuan SM, Sapuan SM, Hamdan MM. 2008. The effect of alkaline treatment on tensile properties of sugar palm fibre reinforced epoxy composites. Mater Des 29 (7): 1285-90.

Dalibard C. 2007. The potential of tapping palm trees for animal production. Livestock feed resources within integrated farming systems. http: //www.fao.org/AG/AGAINFO/resources/documents/frg/ conf96htm /dalibard.htm

Falguera V, Quintero JP, Jimenez A, Munoz JA, Ibarz A. 2011. Edible films and coatings: Structure, active functions and trends in their use. Trends Food Sci Technol 22 (6): 292-303.

Febriyanti N, Hikmat A, Zuhud EAM. 2017. Ethnobotany and potential of palm sugar (Arenga pinnata Merr.) to community of Kasepuhan Pasir Eurih, Desa Sindanglaya, Kabupaten Lebak, Banten. Media Konservasi 22 (2): 171-180. [Indonesian] 
Gunawan R, Uga GR, Iskandar J, Partasasmita I. 2018. Local knowledge of utilization and management of sugar palm (Arenga pinnata) among Cipanggulaan People of Karyamukti, Cianjur (West java, Indonesia). Biodiversitas 19 (1): 93-105.

Irawan B, Rahmayani E, Iskandar J. 2009. Study on variation, usage, processing and management of sugar palm in Rancakalong Village, Rancakalong Sub-district, Sumedang District, West Java. Proceeding the National Seminar Ethnobotany IV, Cibinong 18 May 2008. [Indonesian].

Ishak MR, Sapuan SM, Leman Z, Rahman MZA, Anwar UMK. 2012. Characterization of sugar palm (Arenga pinnata) fibres. Tensile and thermal properties. J Threm Anal Calorim 109: 981-989.

Komarayati S and Poedji H. 1993. Chemical analysis of jackfruit wood (Artocarpus heterophyllus Lamk) from West Java. Jurnal Penelitian Hasil Hutan. 11 (8): 326-328. [Indonesian]

Leman Z, Sapuan SM, Azwan M, Ahmad MMHM, Maleque MA. 2008. The effect of environmental treatments on fiber surface properties and tensile strength of sugar palm fiber-reinforced epoxy composites. Polym Plast Technol Eng 47 (6): 606-12.

Martini E, Roshetko JM, Noordwijk MV, Rahmanulloh A, Mulyoutami E, Joshi L, Budidarsono S. 2012. Sugar palm (Arenga pinnnata (Wurmb Merr.) for livelihoods and biodiversity conservation in the orangutan habitat of Batang Toru, North Sumatra, Indonesia: mixed prospects for domestication. Agrofor Syst 86: 401-417.

Miller RH. 1964. The versatile sugar palm. Principles 8 (4): 115-146.

Misharina TA, Mukhutdinova SM, Zharikova GG, Terenina MB, Krikunova NI, Medvedeva IB. 2010. Formation of flavor of dry champignons (Agaricus bisporus). Prikl Biokhim Mikrobiol 46: 11924.
Mogea J, Seibert B, Smits W. 1991. Multipurpose palms: the sugar palm (Arenga pinnata (Wurmb) Merr.). Agrofor Syst 13: 111-129.

Mujahidin, Sutrisno, Latifah D, Handayani T, Fijridiyanto IA. 2003. Sugar palm cultivation and its prospect. Centre of Plant Conservation in Kebun Raya Bogor-LIPI. Bogor. [Indonesian]

Newing H, Eagle CM, Puri RK, Watson CW. 2011. Conducting research in conservation: a social science perspective. Routledge, London.

Orwa C, Mutua A, Kindt R, Jamnadass R, Anthony. 2009. Agroforestree Database: A Tree Reference and Selection Guide Version 4.

Purba E, Oding A, Liliek P. 2014. Economic value and distribution of palm sugar (Arenga pinnata) in Desa Bukum and Desa Suka Maju, Kecamatan Sibolangit. Peronema For Sci J 3 (2): 1-8.

Sadiq S, Bhatti NH, Hanif MA. 2008. Studies on chemical composition and nutritive evaluation of wild edible mushrooms. JICS 27: 151-4

Sastra HY, Siregar JP, Sapuan SM, Leman Z, Hamdan MM. 2006. Tensile properties of Arenga pinnata fiber-reinforced epoxy composites. Polym Plast Technol Eng. 45: 1-8.

Schroder S. 2010. Bamboo Species, Dendrocalamus - Dendrocalamus giganteus. https: //www.guaduabamboo.com/species/dendrocalamusgiganteus

Siregar AZ. 2016. Inventory of predominat pollinator insects, pests and diseases of Arenga palm. Jurnal Pertanian Tropik 3 (2): 170-176. [Indonesian].

Sujarwo W, Arinasa IBK, Peneng IN. 2010. Potential of Tali Bamboo (Gigantochloa apus) as medicine in Bali. Bul. Litro. 21 (2): 129-137. [Indonesian]

Zulkarnaen RN, Putri SA. 2015. Dendrocalamus spp.: Collection of Giant Bamboo at Kebun Raya Bogor. Pros Sem Nas Masy Biodiv Indon 1 (3): 534-538. [Indonesian] 